\title{
Frontal Plane Projection Angle during Step Down Test in Subjects With and Without Patellofemoral Pain Syndrome
}

\author{
RANA S. YOUSSIF, M.Sc.*; NADIA A. FYAZ, Ph.D.** and KARIMA A. HASSAN, Ph.D.** \\ The Department of Musculoskeletal Disorders and their Surgeries, Faculty of Physical Therapy, \\ Badr* and Cairo** Universities, Egypt
}

\begin{abstract}
Background: Patellofemoral Pain (PFP) is considered one of the most common forms of knee pain. Increased frontalplane knee motion during dynamic activities may play a role in the development of PFP due to alterations in joint loading at the patellofemoral joint and increased stress on the periarticular structures of the patella.

Aim of Study: To determine if there is an alteration of the frontal plane projection angle during step down test in subjects with and without Patellofemoral Pain Syndrome (PFPS).

Subjects and Methods: Forty participants, with age between 18-35 years, 20 PFPS and 20 healthy control group. FPPA angle for both groups was measured by digital video camera and was analyzed by kinovea software for motion analysis during performing Step down test.

Results: There was no significant difference in the median value of FPPA between the affected side in the PFPS group and the healthy group $(p=0.72)$.

Conclusion: PFPS is not linked to altered FFPA during step down task, this finding suggests that assessment of lower extremity kinematics in clinical practice need 3-D motion analysis not only one plane assessment.
\end{abstract}

Key Words: Patellofemoral pain - Frontal plane projection angle - Step down test.

\section{Introduction}

PATELLOFEMORAL Pain (PFP) is defined as pain around or behind the patella aggravated by activities that increase loading and compressive forces of the patellofemoral joint such as squatting, ascending and descending stairs, jumping, or running $[1,2]$. It is also known by such terms as anterior knee pain or patellofemoral dysfunction [3].

Correspondence to: Dr. Rana S. Youssif, The Department of Musculoskeletal Disorders and their Surgeries,

Faculty of Physical Therapy, Badr University, Egypt
PFP is considered one of the most common forms of knee pain, affecting adults, adolescents, and physically active populations [4]. PFPS has been estimated to affect as many as $56 \%$ of the active population [5], with females are likely to develop it twice as males [6]. A valid initial diagnosis of PFP is vital for early appropriate management and prevent the persistence of symptoms [1]

The diagnosis of PFP is mainly based on patients' history elements and physical examination tests, because there are no specific imaging findings either on radiographs or on magnetic resonance imaging to confirm PFP [7].

PFP patients have changes in the alignment between the lower extremity and the trunk, especially during weight-bearing activities [8-10]. This misalignment reduces the contact area of the patella with the femur, and increase pressure exerted on retro patellar cartilage [10]. Despite the causes of pain are little known, it is suggested that local factors (knee joint), proximal (hip joint and trunk) and distal (ankle joint and foot) are directly related [2].

Dynamic frontal-plane motion has been described as a combination of joints motion including the ankle, hip, and knee [11]. Altered frontal and transverse plane hip kinematics during single leg weight-bearing tasks are thought to be important contributors to Patellofemoral Pain (PFP) [12] . In this step down test, the FPPA is measured from a digital image of the lower extremity taken during the descent phase of a single-leg squat. Willson et al., [13] found that healthy female athletes demonstrate a more negative (greater) FPPA compared with healthy male athletes. Measurement of the FPPA during a single-leg squat was found to have 
good intrarater reliability $(\mathrm{ICC} 3,3=0.88) \quad[13]$ Finally, it remains unclear if this test will differentiate subjects with PFPS, many of whom are believed to demonstrate abnormal lower extremity mechanics. The aim of the present study is to investigate if there is an alteration of the frontal plane projection angle during step down test in subjects with PFPS in comparison to healthy subjects.

\section{Participants and methods:}

This study was conducted in the outpatient clinic of the Faculty of Physical Therapy, Cairo University, Egypt. The study extended from October 2017 to September 2018. The aim of the study was to compare the frontal plane projection angle during step down test between subjects with and without Patellofemoral Pain Syndrome (PFPS).

Ethical approval to conduct the research was obtained from the Ethical Committee of Faculty of Physical Therapy, Cairo University, Egypt No: P.T. REC/012/001676-10/9/2017.

\section{Participants:}

A total of 31 patients and 45 healthy subjects were assessed for eligibility criteria. From them, 11 patients and 25 healthy subjects were excluded. Patients were excluded because they did not meet the inclusion criteria $(n=4)$, refused to participate $(n=7)$. Healthy subjects were excluded because they did not meet the inclusion criteria $(n=5)$, refused to participate $(n=20)$. A total of 40 participants entered the study: 20 patients with chronic PFPS and 20 healthy subjects with a range of age (18-35 years). Patients were consecutively recruited from those referred by a physician for physiotherapy because of PFPS. Healthy subjects were recruited from the general population.

Sample size calculation for comparison of the Frontal Plane Projection Angle (FPPA) between subjects with and without PFPS during the singleleg squat test suggested that 20 subjects were required to detect a $5^{\circ}$ difference between groups (variability estimate from Willson et al., (2006) $-\alpha=0.05, \beta=20[13]$.

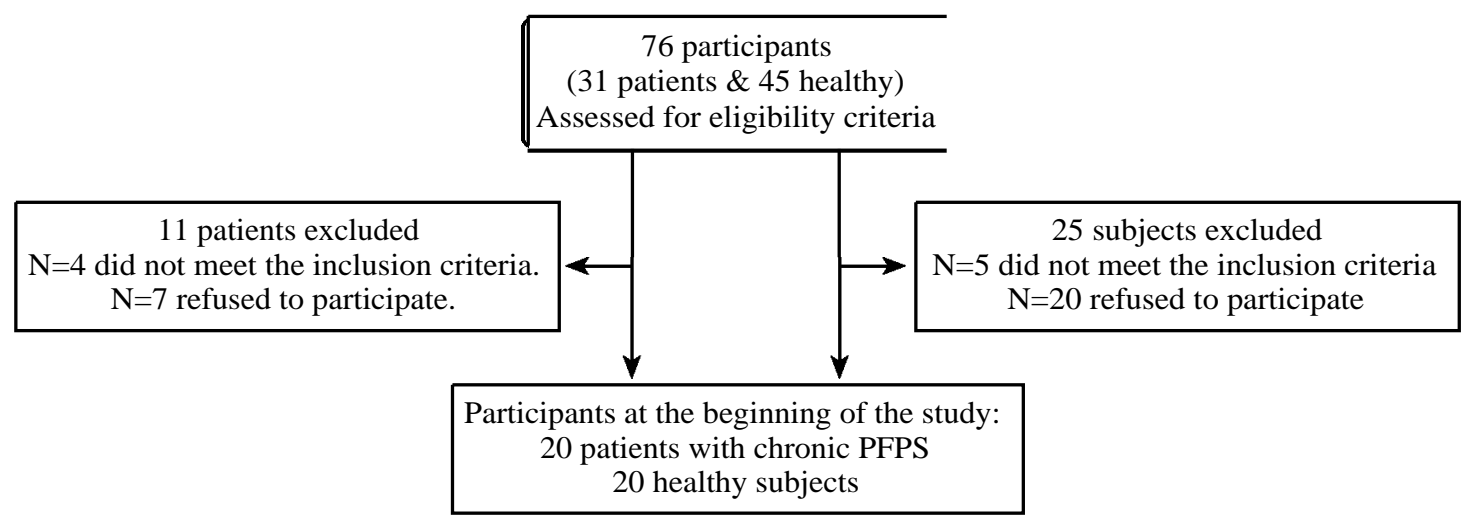

Fig. (1): Participants flow chart.

\section{Subjects and Methods}

\section{Inclusion criteria:}

Patients included in the study were required to have anterior or retropatellar knee pain from at least 2 of the following activities (1) Prolonged Sitting; (2) Stair climbing; (3) Squatting; (4) Running; (5) Kneeling; and (6) Hopping/jumping, to have PFPS for more than 3 months, and Body Mass Index (BMI) below $30 \mathrm{~kg} / \mathrm{m}^{2}$. Additional inclusion criteria for subjects with PFPS were symptoms associated with the therapist performing compression of the patella into the femoral condyles $[\mathbf{1 4 , 1 5}]$ Lastly, subjects with PFPS were required to report greater than 3 on a visual analogue scale. Subjects in the healthy control group were required to be free of lower extremity symptoms.

\section{Exclusion criteria:}

Participants were excluded if they reported any of the following conditions: meniscal or other intraarticular pathologic conditions; cruciate or collateral ligament involvement, traumatic patellar subluxation or dislocation, previous surgery in the lower extremities within the 12 months prior to participation in the study, balance impairments secondary to a vestibular or neurological disorders, or secondary to the use of medication, and lower limb bony/congenital deformity.

\section{Procedures:}

Demographic data were collected from all subjects regarding age, weight, height, and BMI. Participants have signed an informed consent after being familiarized with the objectives, procedures 
of the study, privacy and use of data. All subjects were evaluated by a single examiner with more than 5 years of clinical practice. In cases of bilateral symptoms, the most symptomatic lower extremity was chosen for analysis. The measured lower extremity for the subjects in the healthy control group was chosen randomly.

Prior to testing, markers were placed on the lower extremity of each subject at the midpoint of the femoral condyles, the midpoint of the ankle malleoli, and on the proximal thigh along a line from the Anterior Superior Iliac Spine (ASIS) to the knee marker. Markers were used to determine joint centers as it had been shown to increase intraand inter-rater reliability in comparison to the manual digitization of joint centers via video [16]

From a frontal view, FPPA was measured as the difference from a vertical line (180 degrees) [17]. In another words, when the knee marker was medial to a line from the ankle marker to the thigh marker, the FPPA was positive. The FPPA was negative if the knee marker was lateral to a line from the ankle marker to the thigh marker [18] This method of angle calculation was matched with Räisänen et al., (2018) [19], in which he stated that FPPA was calculated as the intersection of a line created by the ASIS and knee joint center and the line created by the knee joint center and the ankle joint center. Neutral alignment was considered $0^{\circ}$, positive values represented valgus alignment and negative values represented varus alignment.

Subjects stood double legged on the step with height $20 \mathrm{~cm}$. Participants were asked to step down with the untested leg and squatting with the tested leg Fig. (1). The timing of this task was standardized to two seconds for the descent, one second for the toe to touch the ground and two seconds to return to the start, and monitored with a timer. Participants were allowed to perform three trials before the test; subjects received verbal instructions on the performance of step-down without specific directions on the knee and hip alignment [20,21] .

The digital camera placed anterior to subject at a distance from a step of $2 \mathrm{~m}$, at the height of the knee joint in single-leg stance [22]. It was fixed on a tripod to minimize the camera shake to obtain clear pictures. Examiner was edited the video using Kinovea software, place tracking markers on the person's leg, start the analysis, export data to a spreadsheet, find a position, velocity, and acceleration, with this same data find the inverse kinematics of the leg and then graph the results. It's a valid and reliable method of ROM assessment [23-25]

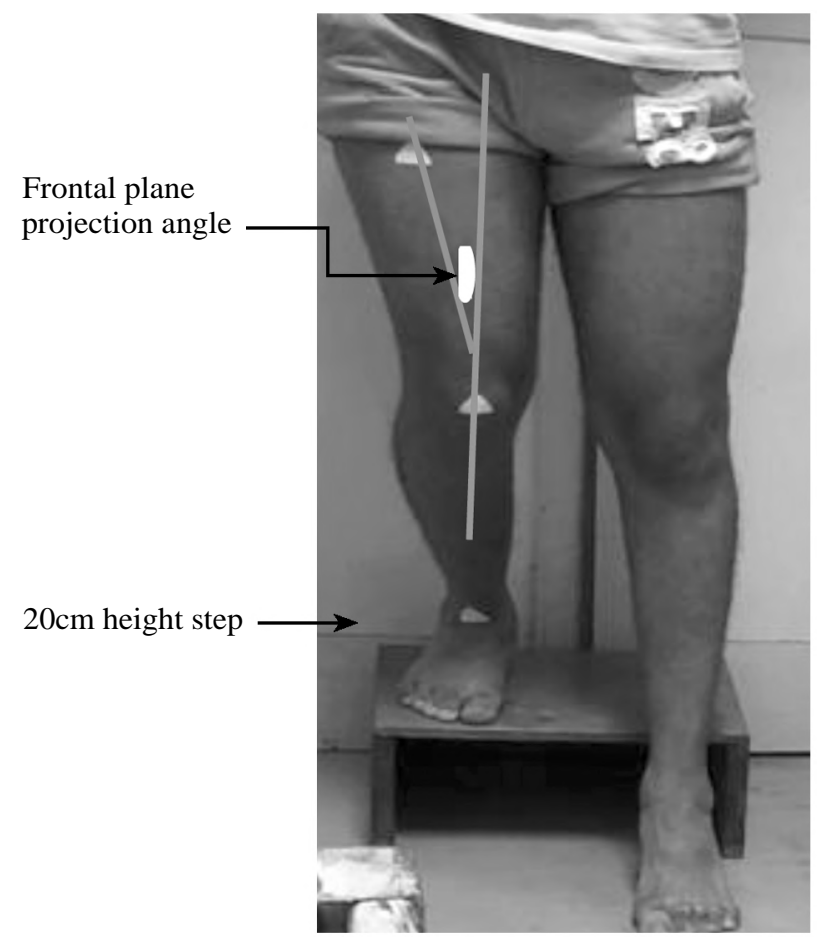

Fig. (2): Markers used to determine the Frontal Plane Projection Angle (FPPA) during single leg step down.

\section{Statistical analysis:}

Descriptive statistics and $t$-test were conducted for comparison of mean age, weight, height, BMI between both groups. Normal distribution of data was checked using the Shapiro-Wilk test for all variables. As FPPA showed nonnormal distribution they follow nonparametric statistics in their comparison. Chi-squared test was conducted for comparison of sex distribution between both groups. Mann-Whitney U-test was conducted for comparison FPPA between both groups.

All statistical tests were performed through the Statistical Package for Social Studies (SPSS) Version 19 for Windows (IBM SPSS, Chicago, IL, USA). With the initial alpha level set at 0.05 .

\section{Results}

Twenty subjects with PFPS and 20 healthy subjects were included in this study. With their mean \pm SD age was $25.5 \pm 3.45$ years, $24.85 \pm 6.07$ years respectively.

Patients' anthropometric characteristics were (mean $\pm \mathrm{SD}$ ) height, weight, and BMI were $66.75 \pm$ $12.59 \mathrm{~kg}, 167.3 \pm 8.79 \mathrm{~cm}$ and $23.68 \pm 3.22 \mathrm{~kg} / \mathrm{m}^{2} \mathrm{re}-$ spectively. Healthy subjects' anthropometric characteristics were (mean \pm SD) height, weight, and BMI were $67.45 \pm 8.9 \mathrm{~kg}, 167.65 \pm 7.77 \mathrm{~cm}$ and $24 \pm$ $2.41 \mathrm{~kg} / \mathrm{m}^{2}$ respectively. An unpaired $t$-test found 
no difference between the healthy subject group and the participants with PFPS for age $(t=0.41$, $p=0.68)$, height $(t=-0.13, p=0.89)$, weight $(t=0.2$, $p=0.84)$, and BMI $(t=0.34, p=0.73)$. The characteristics of PFPS and control groups are summarized in (Table 1).

The sex distribution of the PFPS group revealed that there were 12 females with reported percentage of $60 \%$ while the number of males was 8 with reported percentage of $40 \%$. The dominance of females in the sample is typical of the population of people with PFPS. The sex distribution of normal group revealed that there were 10 females with reported percentage of $50 \%$ and the number of males was 10 with reported percentage of $50 \%$ as shown in (Table 2) and demonstrated in Fig. (2). There was no significant difference between both groups in sex distribution $(p=0.52)$.

Comparison of FPPA between the affected side of PFPS group and normal group, the median FPPA of the affected side in the PFPS group was 4 while in the normal group was 5 , there was no significant difference in the median value of FPPA between the right and left sides $(p=0.25)$ in the normal group. There was no significant difference in the median value of FPPA between the affected side in the PFPS group and the normal group $(p=0.72)$ (Table 3), Fig. (3).

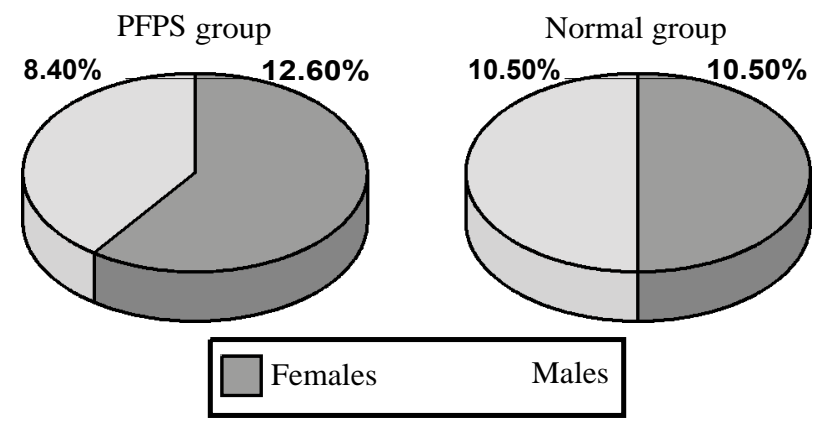

Fig. (3): Sex distribution of PFPS and normal groups.

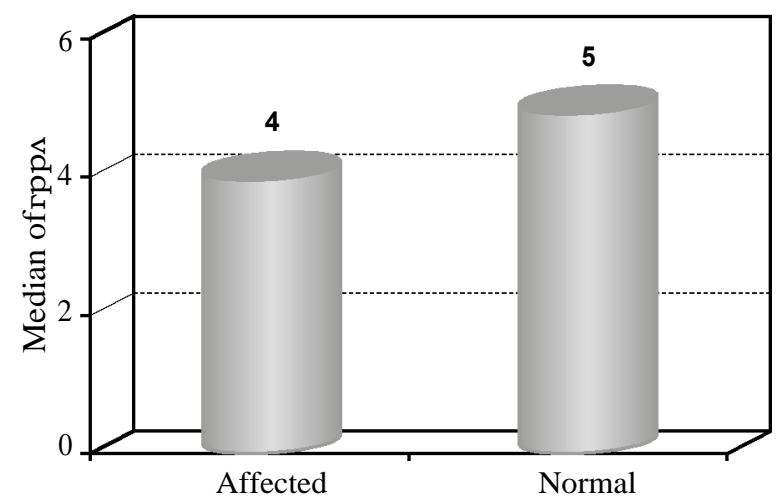

Fig. (4): Median FPPA of the affected side in PFPS group and normal group.
Table (1): Descriptive statistics and $t$-test for the mean age, weight, height, and BMI of PFPS and normal groups.

\begin{tabular}{|c|c|c|c|c|c|c|}
\hline & $\begin{array}{l}\text { PFPS group } \\
X \pm \text { SD }\end{array}$ & $\begin{array}{l}\text { Normal group } \\
\quad X \pm S D\end{array}$ & MD & $\begin{array}{c}t- \\
\text { value }\end{array}$ & $\begin{array}{c}p- \\
\text { value }\end{array}$ & Sig. \\
\hline Age (years) & $25.5 \pm 3.45$ & $24.85 \pm 6.07$ & 0.65 & 0.41 & 0.68 & NS \\
\hline Weight $(\mathrm{kg})$ & $66.75 \pm 12.59$ & $67.45 \pm 8.9$ & -0.7 & -0.2 & 0.84 & NS \\
\hline Height $(\mathrm{cm})$ & $167.3 \pm 8.79$ & $167.65 \pm 7.77$ & -0.35 & -0.13 & 0.89 & NS \\
\hline BMI $(\mathrm{kg} / \mathrm{m} 2)$ & $23.68 \pm 3.22$ & $24 \pm 2.41$ & -0.32 & -0.34 & 0.73 & NS \\
\hline $\begin{array}{l}\text { SD : Standarc } \\
\text { MD : Mean D }\end{array}$ & ifference. & $\begin{array}{l}t \\
p \\
\text { NS }\end{array}$ & $\begin{array}{l}\text { Unp } \\
\text { Prob } \\
\text { Non }\end{array}$ & & lue. & \\
\hline
\end{tabular}

Table (2): The frequency distribution and chi-squared test for comparison of sex distribution between PFPS and normal groups.

\begin{tabular}{lccccc}
\hline & PFPS group & Normal group & $\chi^{2}$ & $p$-value & Sig. \\
\hline Females & $12(60 \%)$ & $10(50 \%)$ & 0.4 & 0.52 & NS \\
Males & $8(40 \%)$ & $10(50 \%)$ & & & \\
\hline$\chi^{2}:$ Chi squared value. & \multicolumn{3}{c}{ NS : Non Significant. } \\
$p$-value : Probability value. & & &
\end{tabular}

Table (3): Comparison of median value of FPPA between the affected side in the PFPS group and normal group.

\begin{tabular}{lccccc} 
& $\begin{array}{c}\text { Affected } \\
\text { median }\end{array}$ & $\begin{array}{c}\text { Normal } \\
\text { median }\end{array}$ & $\begin{array}{c}\text { U- } \\
\text { value }\end{array}$ & $\begin{array}{c}p \text { - } \\
\text { value }\end{array}$ & Sig. \\
\hline FPPA & 4 & 5 & 187 & 0.72 & NS \\
\hline U-value : Mann-Whitney value. & & & \\
$p$-value & $:$ Probability value. \\
NS & $:$ Non Significant.
\end{tabular}

\section{Discussion}

The study hypothesis stated that there would be no difference between the frontal plane projection angle during step down test in subjects with and without Patellofemoral Pain Syndrome (PFPS). The results of this study accept this general hypothesis as there was no difference between the frontal plane projection angle during step down test in subjects with and without Patellofemoral Pain Syndrome (PFPS).

The results of the current study disagreed with the results of Willson et al., [13] in which he found that subjects in the PFPS group demonstrated FPPA measures representative of a more medial position of the knee during single-leg squats by 4.1 . Some of this difference between groups may be due to a more medial position of the knee at the start of the single-leg squat. They explained this difference between groups for two reasons. First, it was likely due to differences in starting position between groups, in which the individuals in the PFPS group were slightly in more medial single-leg stance. Second, was that the differences in hip strength between groups. The difference between our result and this study may be due to the difference in the 
applied activity as they choose single leg squat that needs more balance than step down test used in our study.

Patients who present with PFPS from lateral patellar tracking exhibit greater lateral translation and patellar tilt during weight-bearing conditions compared to non-weight-bearing conditions [26] One biomechanical explanation has attributed lateral patellar maltracking to excessive dynamic knee valgus associated with weak hip abductor muscle strength [27]. This commentary suggested that ipsilateral hip abductor muscle weakness leads to compensatory elevation at the contralateral pelvis. As this happens when viewed in the frontal plane, the ground reaction force vector moves closer to the ipsilateral hip joint center creating an external knee valgus movement during single-leg support. Levinger and his colleagues have demonstrated that patients with PFPS present greater dynamic knee valgus than do controls without PFPS during performing single leg squat [28]

Several functional tests to measure FPPA at dynamic conditions can be found in the literature. Most-widely used ones are single leg squat [13], drop vertical jump [11], drop landing [29] and single leg landing [30], as they simulate real movements and interactions produced during sport practice. Step down test (used in present study) is considered to be less commonly used in the FPPA measurement, although it simulates function (descend stair) that cause major problems to subject with PFPS.

Herrington, [29] investigated the Frontal Plane Projection Angle (FPPA) during Single Leg Squatting (SLS) and hop landing (SLL) tasks in 12 females patients with PFPS and compare their performance to 30 females control and the uninjured limb. They found that in the asymptomatic control group the mean FPPA for SLS was $8.4 \pm 5.1^{\circ}$ and SLL had a mean FPPA of $13.5 \pm 5.7^{\circ}$. In the PFPS group, the mean FPPA for SLS was $16.8 \pm 5.4^{\circ}$ and SLL had a mean FPPA of $21.7 \pm 3.6^{\circ}$, these differences were significant $(p<0.01)$ for both tasks. In other words, patients with PFPS have a greater degree of knee valgus on unilateral limb loading task than either their contralateral asymptomatic limb or an asymptomatic control group. His findings disagreed with the results of the present study may be due to the homogeneity in their sample that was restricted only to female subjects, and using different functional task.

\section{Conclusion:}

PFPS is not linked to altered FFPA during step down task, these findings suggest that assessment of lower extremity kinematics in clinical practice need 3-D motion analysis not only one plane assessment.

\section{Financial support and sponsorship:}

Nil.

\section{Conflicts of interest:}

There are no conflicts of interest.

\section{References}

1- CROSSLEY K.M., CALLAGHAN M.J., COLLINS N.J. and BARTON C.J.: Patellofemoral pain consensus statement from the 4 th International Patellofemoral Pain Research Retreat, Manchester. Part 2: Recommended physical interventions (exercise, taping, bracing, foot orthoses and combined interventions). British Journal of Sports Medicine, 50 (14): 44-52, 2016.

2- WITVROUW E., CALLAGHAN J., STEFANIK J., NOEHREN B., et al.: Patellofemoral pain: Consensus statement from the ${ }^{3 \mathrm{rd}}$ International Patellofemoral Pain Research Retreat held in Vancouver, 48 (6): 411-14, 2013.

3- DURSUN N., DURSUN E. and KILIC Z.: Electromyographic biofeedback controlled exercise versus conservative care for patellofemoral pain syndrome. Archives of Physical Medicinee and Rehabilitation, 82 (12): 1692-5, 2001.

4- SMITH B.E., SELFE J., THACKER D., HENDRICK P., et al.: Incidence and prevalence of patellofemoral pain: A systematic review and meta-analysis. PLOS ONE, 13 (1): $1-18,2018$

5- THIJS Y., CLERCQ D., De ROOSEN P. and WITROUW E.: Gait-related intrinsic risk factors for patellofemoral pain in novice recreational runners. British Journal of Sports Medicine, 42 (6): 466-71, 2008.

6- BOLING M.C., PADUA D., MARSHALL S., GUSKIEWICZ K., et al.: Gender differences in the incidence and prevalence of patellofemoral pain syndrome. Scandinavian Journal of Medicine \& Science in Sports, 20 (5): 725-30, 2010.

7- VAN DER HEIJDEN R.A., OEI E.H., BRON E.E., et al.: No difference on quantitative magnetic resonance imaging in patellofemoral cartilage composition between patients with patellofemoral pain and healthy controls. American Journal of Sports Med., 44 (5): 1172-8, 2016.

8- NAKAGAWA T.H., MORIYA E.T., MACIEL C.D. and SERRÃO F.V.: Trunk, pelvis, hip, and knee kinematics, hip strength, and gluteal muscle activation during a singleleg squat in males and females with and without patellofemoral pain syndrome. Journal of Orthopedic and Sports Physical Therapy, 42 (6): 491-501, 2012.

9- WILLSON J.D.: Lower extremity mechanics of females with and without patellofemoral pain across activities with progressively greater task demands. Clinical Biomechanics, 23 (2): 203-11, 2008.

10-POWERS C.M.: The Influence of Altered Lower-Extremity Kinematics on Patellofemoral Joint Dysfunction: A Theoretical Perspective. The Journal of Orthopaedic and Sports Physical Therapy, 33 (11): 639-46, 2003. 
11- HEWETT T.E., MYER G.D., FORD K.R., HEIDT R.S., et al.: Biomechanical measures of neuromuscular control and valgus loading of the knee predict anterior cruciate ligament injury risk in female athletes. A prospective study. The American Journal of Sports Medicine, 33 (4): 492-501, 2006.

12- COLLINS N., HART H., GRRICK L., SCHACHE A., et al.: Single leg squat hip pathomechanics are associated with ankle dorsiflexion restriction in people with patellofemoral pain. Journal of science and medicine in sport, 18: 1-22, 2014.

13- WILLSON J.D., IRELAND M.L. and DAVIS I.: Core strength and lower extremity alignment during single-leg squats. Medicine \& Science Sports Exercise, 38 (5): 94552, 2006.

14- FREDERICSON M. and YOON K.: Physical examination and patellofemoral pain syndrome. American Journal of Physical Medicine and Rehabilitation, 85 (3): 234-43, 2006.

15- FULKERSON J., BUUK D. and POST W.: Disorders of the patellofemoral joint. Williams \& Wilkins ${ }^{3 r d}$ edition: 12-7, 1997.

16-BARTLETT R., BUSSEY M. and FLYGER N.: Movement variability cannot be determined reliably from no-marker conditions. Journal of Biomechanics, 39 (16): 3076-79, 2006.

17- RAMIREZ M., NEGRETE R., HANNEY W., KOLBER M.J.: Quantifying frontal plane knee kinematics in subjects with anterior knee pain: The reliability and concurrent validity of 2D motion analysis International Journal of Sports Physical Therapy, 13 (1): 86-93, 2018.

18- MUNRO A., HERRINGTON L. and CAROLAN M.: Reliability of 2-dimensional video assessment of frontalplane dynamic knee valgus during common athletic screening tasks. Journal of Sport Rehabilitation, 21 (1): 7-11, 2012.

19- RÄISÄNEN A.M., PASANEN K., KROSSHAUG T., VASANKARI T., et al.: Association between frontal plane knee control and lower extremity injuries: A prospective study on young team sport athletes. British Medical Journal Open Sport \& Exercise Medicine, 4 (1): 1-10, 2018.

20- ALMONROEDER T., DEJARLAIS B., WILLSON J.D., KERNOZEK T.W., et al.: Effects of a movement training program on hip and knee joint frontal plane running mechanics. International Journal of Sports Physical Therapy, 7 (6): 637-46, 2012.

21- BELL-JENJE T., OLIVIER B., WOOD W., ROGERS S., et al.: The association between loss of ankle dorsiflexion range of movement and hip adduction and internal rotation during a step down test. Manual Therapy, 21: 256-61, 2015.

22- WILLSON J.D. and DAVIS I.R.: Utility of the Frontal Plane Projection Angle in Females With Patellofemoral Pain. Journal of Orthopaedic \& Sports Physical Therapy, 38 (10): 606-15, 2008.

23- EL-RAHEEM R.M.A., KAMEL R.M. and ALI M.F.: Reliability of using Kinovea program in measuring dominant wrist joint range of motion. Trends in Applied Sciences Research, 10 (4): 224-30, 2015.

24- ELWARDANY S.H., EL-SAYED W.H. and ALI M.F.: Reliability of kinovea computer program in measuring cervical range of motion in sagittal plane. Open Access Library Journal, 2 (9): 1-10, 2015.

25- PADULO J., FILINGERI D., CHAMARI K., MIGLIACCIO G.M., et al.: Acute effects of whole-body vibration on running gait in marathon runners. Journal of Sports Sciences, 32 (12): 1120-6, 2014.

26- DRAPER C.E., BESIER T.F. and FREDERICSON M.: Differences in patellofemoral kinematics between weightbearing and non-weight-bearing conditions in patients with patellofemoral pain. Journal of Orthopaedic Research, 29 (3): 312-7, 2010.

27- POWERS C.M.: The influence of abnormal hip mechanics on knee injury: A biomechanical perspective. The Journal of Orthopaedic and Sports Physical Therapy, 40 (2): $42-$ 51, 2010.

28- LEVINGER P., GILLEARD W. and COLEMAN C.: Femoral medial deviation angle during a one-leg squat test in individuals with patellofemoral pain syndrome. Physical Therapy in Sport, 8 (4): 163-8, 2007.

29- HERRINGTON LEE: Knee valgus angle during single leg squat and landing in patellofemoral pain patients and controls. The Knee Journal, 21 (2): 514-7, 2014.

30- LAWRENCE R.K.I., KERNOZEK T.W., MILLER E.J. and TORRY M.R.: Influences of hip external rotation strength on knee mechanics during single-leg drop landings in females. Clinical Biomechanics, 23 (6): 806-13, 2008. 


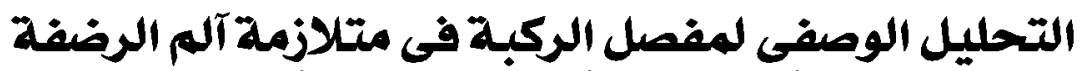

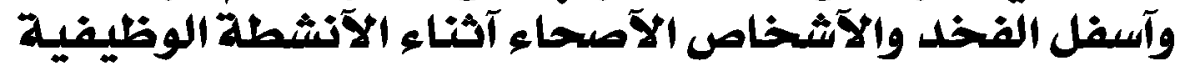

متلازمة آلم الرضفة تعتبر الآكثر إنتشارا بين آلام مفصل الركبة. إعتقاد آن زيادة الحركة الآمامية لمفصل الركبة آثناء الآنشطة الوظيفية

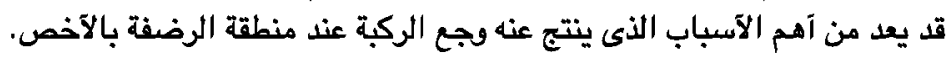

الهدف الرئيسى من إجراء هذه الدراسة هى التحليل الوصفى لمفصل الركبة فى الآثخاص الذين يعانون من متلازمة آلم الرضفة وآسفل الفخد والآثخاص الآصحاء آثناء الآنشطة الوظيفية، وذلك اللتاكل من وجول زاوية الإنحراف في متلازمة آلم الرضفة وآسفل الفخد.

آجريت الدراسة على عدد آريعنف شخصا، عشنون من مرضى متلازمة آلم الرضفة وآسفل الفخد ويقابلهم علد عشرنف من الذين لا يعانف

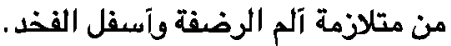

التحليل الوصفى لمفصل الركبة قد تم بإستخدام برنامج الكينوفا سوفت وير ثنائى الآبعاد التحليل الحركة آثناء آداء نوع من آنواع الآنثطة اليومية وهو إختبار نزول السلم.

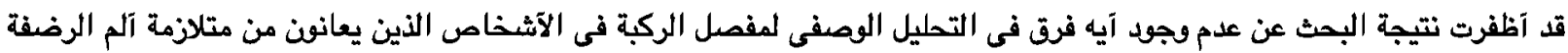

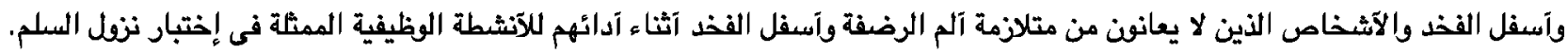
الإستنتاج الرئيسى من هذه الدراسة هو آنه لا توجد علاقة بين متلازمة آلم الرضفة وآسفل الفخد والإنصراف الآمامى لمفصل الركبة. هذا الإستنتاج يشير إلى ضرودة إستخدام برنامج تحليل حركة ثلاثى الآبعاد وليس فقط ثنائى الأيس الآبعاد . 